\title{
Effect of Ethrel treatment of wheat on the susceptibility to fungal diseases and on the root zone mycoflora of this plant*
}

\author{
MARIAN MICHNIEWICZ, ANTONI ROŻEJ, EWELINA CZERWIŃSKA, \\ GRAŻYNA KRUSZKA
}

Institute of Biology, Copernicus University, Gagarina 9, 87-100 Toruń, Poland

(Received: October 15, 1984)

\begin{abstract}
Wheat cv. 'Grana' grown under field conditions was sprayed with solutions of Ethrel (500, 1000 and $3000 \mathrm{ppm}$ ) in three phases of plant development: tillering, appearance of the first node of a culm and coming into ear. The plant analysis was done seven days after the last spray. It has been found that Ethrel treatment decreased the length of a straw, reduced plant susceptibility to Cercosporella herpotrichoides infection and that with species of the Fusarium genus. On the other hand it increased wheat susceptibility to Erysiphe graminis infection, and particularly to that with Puccinia triticina. Ethrel slightly affected the mycoflora of the root zone - it significantly increased only the percentage of species of the genus Penicillium and reduced that of Mucor hiemalis. The Ethrel effect on the specific composition of rhizoplane mycoflora proved to be insignificant.
\end{abstract}

\section{INTRODUCTION}

Ethrel - a compound where 2-chloroethylphosphonic acid is an active component, an ethylene-releasing compound, is being increasingly used in agriculture (Nickell, 1982). It is also one of the components of Camposan, used as lodging reducer in grain growing (Hoffmann, 1978).

Information on the ethylene effect on the progress of pathogenesis caused by parasitic fungi is scarce and controversial. Increased resistance obtained by applying ethylene has been found in Ipomoea batatas infected with Ceratocystis fimbriata (Clare et al., 1966, Stahmann et al., 1966), in apples infected with Gloeosporium

* This study was financed under the project MR II 7. 
album (Lockhart et al., 1968) and in wheat infected with Puccinia recondita (Levin, 1984). It has also been revealed that the introduction of ethylene - air mixture into the soil has inhibited growth of many species of soil fungi (Smith, 1973), Kravec (1982) quotes the work of Sitnik et al., in which it has been demonstrated that Ethrel applied in storing sugar beet clumps has prevented rot.

According to Chalut $z$ et al. (1969), the role of ethylene in developing resistance to pathogens consists in stimulating the host plant to produce MMHD (3-methyl6-methoxy-8-hydroxy-3,4,-dihydroisocumarin), a compound showing the properties of phytoalexins. According to Boller et al. (1983), ethylene inducement of the endochitinase enzyme, whose function is to protect the plant against fungal and bacterial pathogens accounts for the resistance - developing effect of this compound.

There is, however, a number of reports pointing out that plants subjected to ethylene are less resistant to fungal diseases. Thus, ethylene has increased rotting in strawberries caused by Botrytis cinerea (El-Kazzar et al., 1983a) has reduced the resistance of wheat to Puccinia graminis (Daly et al., 1970), of barley to $\mathrm{Hel}$ minthosporium sativum (Blankenage1, 1981), of soybean to Cylindrocladium clotariae (Forthum, 1983) and of Douglas fir to Fusarium oxysporum (Graham and Linderman, 1981).

The effect of ethylene on the extent of plant infection with fungi may depend on the pathogen and the infected plant taxonomic status, on the concentration and the developmental stage in which the compound has been applied. Thus, ethylene has prevented the development of a disease of tangerine fruits caused by Colletotrichum gloesporicides if it has been applied a few days before inoculation. Introduced directly after infection it has resulted in the disease which without ethylene would not develop (Brown and Barmore, 1977). Likewise, ethylene has enhanced resistance to Penicillium italicum in orange fruits only if applied before inoculation (El-Kazzar et al., 1983b, c).

According to Dehne and Spengler (1982), ethylene increases the plant sensitivity to fungal diseases caused by perthotrophic fungi but decreases their sensitivity to biotrophic fungi.

Our previous laboratory experiments have proved, Ethrel to inhibit strongly growth and development of Fusarium culmorum irrespective of the isolates pathogenicity to wheat seedlings (Michniewicz et al., 1983). The present study is intended to answer the question whether the inhibiting effect of Ethrel on the growth and development of this fungus will show under field conditions and what effect the preparation will have on the growth and development of other fungi living on wheat.

Considering the fact that treating the plant above-ground parts with growth regulators, such as gibberellin or auxin, affects the quantitative (Sullia, 1968; Sethunathan, 1970a; Balasubramanian and Rangaswami, 1973) and qualitative (Sethunathan, 1970b) composition of the rhizosphere, it has been decided 
to include in the study the analysis of an effect of Ethrel - treatment of plants on the specific composition of the root mycoflora.

\section{MATERIAL AND METHODS}

Field experiments were conducted in the years 1982-1984 on winter wheat $\mathrm{cv}$. 'Grana', on the farm Koniczynka belonging to the Experimental Agricultural Station of the Copernicus University in Torun. In $3 \mathrm{~m}^{2}$ plots Ethrel produced by Amchem was introduced in the form of spray, the concentrations being $0,500,1000$ and $3000 \mathrm{ppm}$, with $0.05 \%$ Tween 20 as solvent. The treatment was applied three times in three developmental stages of the plant: tillering, appearance of the first node and early stage of coming into ear. There were sprayed $360 \mathrm{ml}$ of solution per plot.

The activity of the compound towards the plant was analyzed by measuring the straw lengths.

The assessment of the plant infection with Cercosporella herpotrichoides Fron., Fusarium sp., Erysiphe graminis DC. f. tritici Marchal, Puccinia triticina Erikss. was made seven days after the last spraying.

Infection of the base of a straw with Cercosporella herpotrichoides and Fusarium sp. was estimated according to the three-grade scale after Bojarczuk and Bojarczuk (1974) by determining the percentage damage done to a tissue by a given parasite. Infection with Erysiphe graminis was assessed on the next to flag leaves, and infection with Puccinia triticina on the flag leaves of wheat. The plant health condition was studied according to a five-grade scale by determining the percentage area of leaves occupied by a given parasite (Mikołajska, 1967).

The data obtained from the analysis of tissue damage were used to calculate the total infection degree as percentage according to Tupieniewicz's formula ( $\mathrm{Nau}$ mov, 1948).

The experiments were carried out in six replications. The effect of Ethrel on the plant growth and the extent of infection with each parasite were studied in 600 plants (100 plants from each plot).

The effect of a treatment on the specific composition of rhizosphere and rhizoplane mycoflora was also studied. The fungi from the rhizosphere soil were isolated by the plate method (Peterson, 1958), those from the root surface by Harley and Ward's (1955) method modified by Peters on (1958). Incubation of the plates (in 5 replications) with a suspension of the rhizopshere soil and with root fragments was conducted for 7 days at $22^{\circ} \mathrm{C}$. After that time the fungi were transferred to agar slands made from glucose-potato medium. The fungi were identified after a two weeks' incubation at temp. of $22^{\circ} \mathrm{C}$ on glucose-potato medium in Petri dishes.

Since the results of all the experiments obtained in each year were convergent, only experiment data from 1984 are presented in the paper. The results have been analyzed statistically. The least significant difference (LSD) was calculated. 


\section{RESULTS AND DISCUSSION}

Ethrel applied in all concentrations proved to be active in relation to the studied plants and induced a pronounced shortening of a straw, i.e. it acted in a way which is typical of this preparation (Table 1).

Table 1

Effect of Ethrel on the length of a wheat straw (without ears)

\begin{tabular}{crccc}
\hline \multirow{2}{*}{ Value } & \multicolumn{4}{c}{ Ethrel concentrations (ppm) } \\
\cline { 2 - 5 } & \multicolumn{1}{c}{0} & 500 & 1000 & 3000 \\
\hline cm & 82.2 & $67.0^{\mathrm{a}}$ & $60.8^{\mathrm{a}}$ & $47.3^{\mathrm{a}}$ \\
$\%^{*}$ & 100.0 & 81.5 & 74.0 & 57.5 \\
\hline
\end{tabular}

* In relation to control.

a Differences in relation to control significant at $\mathbf{P}=\mathbf{0 . 0 0 1}$.

Ethrel inhibited the development of Cercosporella herpotrichoides and of the genus Fusarium species on wheat, and stimulated the development of Erysiphe graminis, and particularly that of Puccinia triticina (Tables 2 and 3). This was indicated in the first place by the degree of infection of wheat (Table 2), and in the case of Puccinia triticina also by the number of plants infected. A stimulating effect of Ethrel on the number of plants infected with Erysiphe graminis was found only after applying it in the lowest concentration.

Our data then disagree with the results obtained by Dehne and Spengler (1982), who claim that ethylene inhibits the development of Erysiphe graminis on wheat. Our results also contradict these authors' conclusion saying that ethylene inhibits the development of biotrophic fungi, and stimulates that of perthotrophic fungi. In our experiments converse results were obtained: ethylene inhibited the development of perthotrophic fungi, Cercosporella herpotrichoides and Fusarium sp., and stimulated the development of biotrophic fungi, Erysiphe graminis and Puccinia triticina.

The results of our experiments and literature data presented in the introduction indicate that at the present stage of our knowledge it is impossible to draw general conclusions concerning the effect of ethylene on the plant resistance to fungal pathogens. This resistance depends on many factors, such as the taxonomic status of both the plant and the pathogen, the time of application of the preparation and its concentration, environmental conditions etc.

The results of the experiments on the effect of Ethrel treatment of wheat on the composition of the mycoflora of the root zone have been presented in Figure 1. From the data presented in this figure it appears that in the plant rhizosphere there dominated species of the genus Penicillium, while in the rhizoplane also those of the Fusarium genus.

Ethrel affected the specific composition of the root zone only to a small extent. It caused a statistically significant increase in the percentage of species of the genus 
Table 2

Effect of the wheat treatment - with Ethrel on the degree of injury (in p.c.) of plants by pathogenic fungi*

\begin{tabular}{|c|c|c|c|c|}
\hline \multirow{2}{*}{ Pathogen } & \multicolumn{4}{|c|}{ Ethrel concentrations (ppm) } \\
\hline & 0 & 500 & 1000 & 3000 \\
\hline Cercosporella herpotrichoides & $4.4(100.0)$ & $4.2 \quad(95.4)$ & $3.5^{\mathrm{a}} \quad(79.5)$ & $1.4^{\mathrm{a}} \quad(31.8)$ \\
\hline Fusarium sp. & $43.4(100.0)$ & $34.3^{\mathrm{a}} \quad(79.0)$ & $34.2^{\mathrm{a}} \quad(78.8)$ & $34.0^{\mathrm{a}} \quad(78.3)$ \\
\hline Erysiphe graminis & $12.1(100.0)$ & $15.8^{\mathrm{a}}(130.6)$ & $15.4^{\mathrm{a}}(127.3)$ & $14.2(117.4)$ \\
\hline Puccinia triticina & $9.0(100.0)$ & $14.9^{\mathrm{a}}(165.5)$ & $14.7^{\mathrm{a}}(163.3)$ & $16.0^{\mathrm{a}}(177.8)$ \\
\hline
\end{tabular}

* In parentheses p.c. in relation to control.

a Differences in relation to control significant at $P=0.001$.

Table 3

Effect of the wheat treatment - with Ethrel on the percent age of plants injured by pathogenic fungi*

\begin{tabular}{|c|c|c|c|c|}
\hline \multirow{2}{*}{ Pathogen } & \multicolumn{4}{|c|}{ Ethrel concentrations (ppm) } \\
\hline & 0 & 500 & 1000 & 3000 \\
\hline Cercosporella herpotrichoides & $11.3(100.0)$ & $(95.6)$ & $8.8^{\mathrm{b}}(77.9)$ & $4.0^{\mathrm{a}} \quad(35.4)$ \\
\hline Fusarium sp. & $74.5(100.0)$ & $73.8 \quad(99.1)$ & $70.8^{\mathrm{b}} \quad(95.0)$ & $64.8^{\mathrm{a}} \quad(87.0)$ \\
\hline Erysiphe graminis & $59.3(100.0)$ & $71.0^{\mathrm{a}}(119.7)$ & $58.8 \quad(99.2)$ & $48.0^{\mathrm{b}} \quad(80.9)$ \\
\hline Puccina triticina & $56.8(100.0)$ & $85.3^{\mathrm{a}}(150.2)$ & $86.3^{a}(151.9)$ & $91.2^{\mathrm{a}}(160.6)$ \\
\hline
\end{tabular}

* In parentheses p.c. in relation to control.

ab Differences significant in relation to control at: $a-P=0.001, b-P=0.01$. 
Penicillium and a decrease in the percentage of Mucor hiemalis. These variations were statistically significant at $\mathbf{P}=0.001$. The changes in the percentages of the remaining species occurring in the rhizosphere and the changes in the mycoflora of the rhizoplane were statistically insignificant.
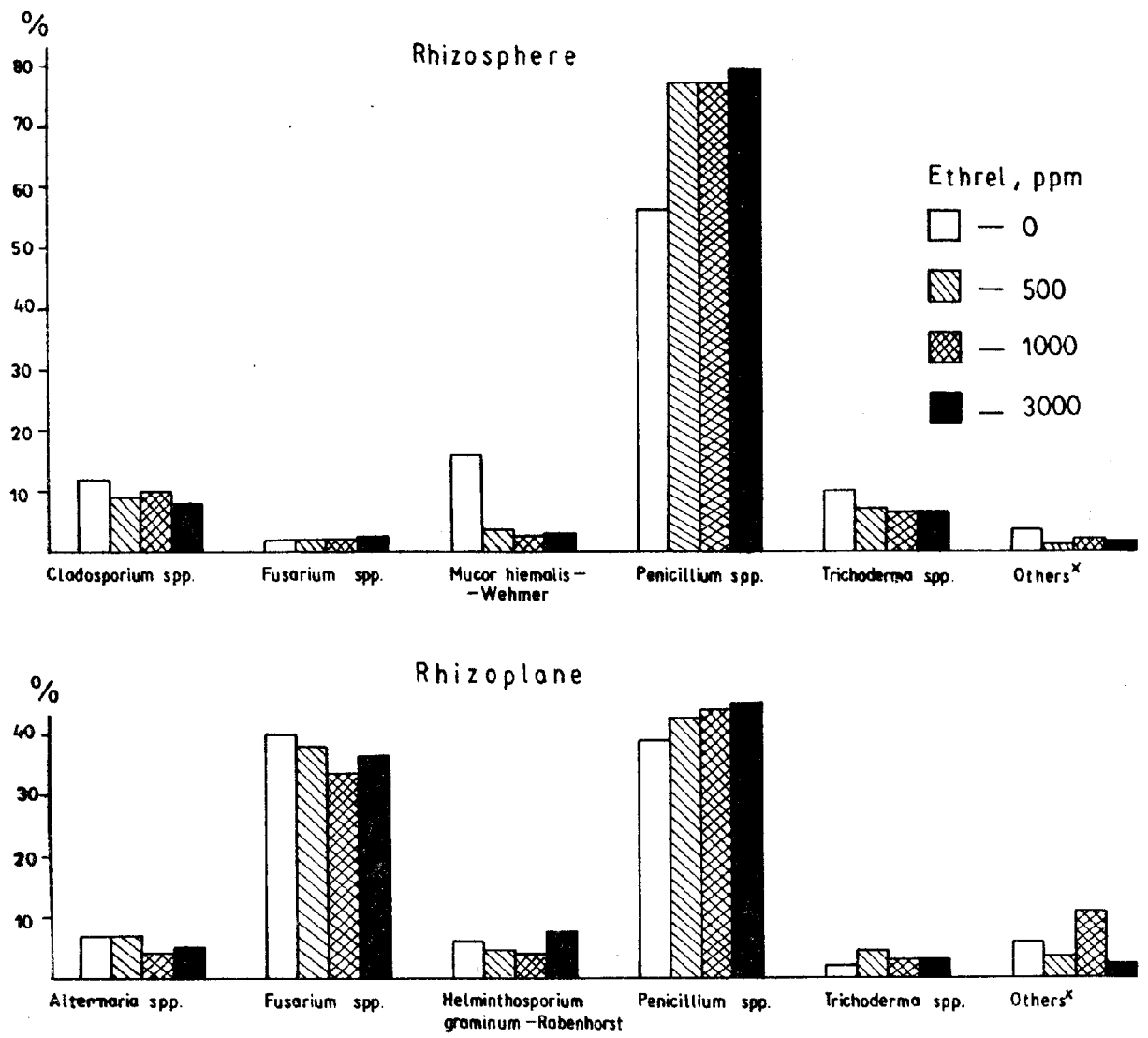

Fig. 1. Effect of the treatment of wheat with Ethrel on the mycoflora composition in the root zone

* Others: Rhizosphere - Cephalosporium roseo-griseum Saksena, Chrysosporium merdarium (Link) Carmichael, Helminthosporium graminum Rabenhorst, Papularia spaerosperma (Persoon) v. Hohnel, Phoma glomerata (Corda) Wollenweber and Hochapfel, Verticillium agaricinum (Link) Corda. Rhizoplane - Cylindrocarpon didymum (Hartung) Wollenweber, H. graminum Rabenhorst, Epicoccum nigrum Link, V. album (Preuss)

\section{REFERENCES}

Balasubramanian A., Rangaswami G., 1973. Influence of foliar application of chemicals on the root exudation and rhizosphere microflora of Sorghum vulgare and Crotalaria juncea. Folia Microbiol. 28: 492-498.

Blankenagel R., 1981. Einfluss von Wachstumsregulatoren auf die Krankenresistenz und den Ertrag unter praktischen Anbaulodingungen. Mitteilungen aus der Biologischen Bundesanstalt für Land und Forstwirschaft. Berlin-Dahlem 203: 90. 
Bojarczuk J., Bojarczuk M., 1974. Wspóldziałanie odmian pszenicy ze szczepami grzyba Cercosporella herpotrichoides Fron. Hod. Roślin Aklim. Nas. 18: 313-326.

Boller T., Gehri A., Mauch F., Vögeli V., 1983. Chitinase in bean leaves induction by ethylene, purification, properties, and possible function. Planta 157: 22-31.

Brown G. E., Barmore C. R., 1977. The effect of ethylene on susceptibility of Robinson tangerines to antracenose. Phytopath. 67: 120-123.

Chalutz E., DeVay J. E., Maxle E. C., 1969. Ethylene-induced isocoumarin formation in carrot root tissue. Plant Physiol. 44: 235-241.

Clare B., Weber D. J., Stahmann M. H., 1966. Peroxidase and resistance to Ceratocystis in sweet potato increased by volatile materials. Science 153: 62-63.

Daly J. M., Seevers P. M., Ludden P., 1970. Studies on wheat stem rust resistance controlled at the Sr-G locus. III. Ethylene and disease reaction. Phytopath. 60: 1648-1652.

Dehne H.-W., Spengler G., 1982. Untersuchungen zum Einfluss von Ethephon auf Pflanzenkrankheiten. Phytopath. Z. 104: 27-38.

El-Kazzar M. K., Sommer M. F., Fortlage R. J., 1983a. Effect on different atmospheres on postharvest decay and quality of fresh strawberries. Phytopath. 73: 282-285.

El-Kazzar M. K., Sommer N. F., Kader A. A., 1983b. Ethylene effects on in vitro and in vivo growth of certain postharvest fruit-infecting fungi. Phytopath. 73: 998-1001.

El-Kazzar M. K., Chardas A., Kader A. A., 1983c. Physiological and compositional changes in orange fruit in relation to modification of their susceptibility to Penicillium italicum by ethylene treatments. J. Am. Soc. Hort. Sci. 108: 618-621.

Forthum B. A., 1983. Effects of growth regulators and Nematodes on Cylindrocladium black root rot of soybean. Plant Disease 67: 282-284.

Graham J. H., Linderman R. G., 1981. Effect of ethylene on root growth ectomycorrhiza formation and Fusarium infection of Douglas - fir. Can. J. Bot. 59: 149-155.

Harley J. L., Ward J. S., 1955. A method of studying active mycelia on living roots and other surface in the soil. Trans. Brit. Mycol. Soc. 8: 104-119.

Hoffmann G., 1978. Camposan - ein Intensivierungsfaktor in der Winterroggenproduktion. Tag. Ber. Akad. Landwirtschaft - Wiss. DDR, Berlin 263: 5-8.

Kravec A. F., 1982. Rol issledovanii fizjologii bolnogo rastieniya. Fiziol. biokhim. Kulturnykh rastienii 14 : $538-544$.

Levin I. M., 1984. Vliyanie fitogormonov na intensivnost rozvitiya buroi rzhavchiny na izolirovannykh listyakh pshenicy. Fiziol. rast. $31: 356-361$.

Lockhart C. L., Forsyth F. R., Eaves C. A., 1968. Effect of ethylene on development of Gloeosporium album in apple and on growth of the fungus in culture. Can. J. Plant Sci. 48: 557-559.

Michniewicz M., Czerwińska E., Rożej B., Bobkiewicz W., 1983. Control of growth and development of isolates of Fusarium culmorum (W. G. Sm.) Sacc. of different pathogenicity to wheat seedlings by plant growth regulators. II. Ethylene. Acta Physiol. Plant. 5: $189-198$.

Mikołajska J., 1967. Stosunki anatomiczne w różnych odmianach Hordeum distichon L. zakażonych przez Erysiphe graminis hordei Marchal. Studia Soc. Sci. Tor. Sec. D7, 5: 1-51.

Naumov N. A., 1948. Spravochnik agronoma po zashchite rastenii. O. G. I. Z. Moskva-Leningrad.

Nickell L. G., 1982. Plant growth regulators. Agricultural uses. Springer Ver., Berlin, Heidelberg, New York.

Peterson E. A., 1958. Observations of fungi associated with plant roots. Can. J. Microbiol. 4: 257-265.

Sethunathan N., 1970a. Foliar sprays of growth regulators and rhizosphere effect in Cajanus cajan Millsp. I. Quantitative changes. Plant and Soil 33: 62-70.

Sethunathan N., 1970b. Foliar sprays of growth regulators and rhizosphere effect in Cajanus cajan Millsp. II. Qualitative changes in the rhizosphere and certain metabolic changes in the plant. Plant and Soil 33: 71-80. 
Smith A. M., 1973. Ethylene as a cause of soil fungistasis. Nature 246: 311-313.

Stahmann M. A., Clare B. G., Woodbury W., 1966. Increased disease resistance and enzyme activity induced by ethylene and ethylene production by black rot infected sweet potato. Plant Physiol. 41: 1505-1512.

Sullia S. B., 1968. Effect of foliar spray of hormones on the rhizosphere mycoflora of leguminous weeds. Plant and Soil 29: 292-298.

Wplyw stosowania Ethrelu w uprawie pszenicy na porażenie roślin przez grzyby pasożytnicze i na skład mykoflory korzeniowej

\section{Streszczenie}

Pszenice ozimą odmiany 'Grana' uprawianą w warunkach polowych opryskiwano roztworem Ethrelu $(500,1000$ i $3000 \mathrm{ppm})$ w trzech fazach rozwoju rośliny: krzewienia, pierwszego kolanka i wczesnego kłoszenia. Oceny porażenia roślin dokonano po 7 dniach po ostatnim oprysku. Stwierdzono, że traktowanie roślin Ethrelem skracało długość źdźbeł, zmniejszalo wrażliwość roślin na porażenie przez Cercosporella herpotrichoides i gatunki z rodzaju Fusarium, natomiast zwiększało wrażliwość pszenicy na porażenie przez Erysiphe graminis, a zwlaszcza przez Puccinia triticina. Ethrel wplywał w niewielkim stopniu na mykoflore strefy korzeniowej; zwiększał tylko statystycznie istotnie udział gatunków z rodzaju Penicillium i zmniejszał udział Mucor hiemalis w mykoflorze ryzosfery. Wpływ Ethrelu na skład gatunkowy ryzoplany okazal się nieistotny. 